\title{
PHOSPHOGYPSUM AND VINASSE APPLICATION: SOIL CHEMICAL PROPERTIES AND ALFALFA PRODUCTIVITY AND NUTRITIONAL CHARACTERISTICS ${ }^{1}$
}

\author{
RONALDO DO NASCIMENTO ${ }^{2} *$, JULIANA APARECIDA DE SOUZA ${ }^{2}$, ADÔNIS MOREIRA $^{3}$, LARISSA \\ ALEXANDRA CARDOSO MORAES ${ }^{3}$
}

\begin{abstract}
The objective of this work was to evaluate the effects of the application of phosphogypsum and vinasse on soil chemical properties and productivity and nutritional characteristics of alfalfa (Medicago sativa). The experiment was conducted in a randomized block design, using a $3 \times 5$ factorial arrangement, with three vinasse rates $\left(0,150\right.$ and $\left.300 \mathrm{~m}^{3} \mathrm{ha}^{-1}\right)$ and five phosphogypsum rates $\left(0,3,6,9\right.$ and $12 \mathrm{Mg}$ ha $\left.{ }^{-1}\right)$. The alfalfa chemical composition and shoot dry matter (SDW) and soil chemical properties (in the layers 0.0-0.2 and 0.21-0.4 m) were evaluated. The vinasse rates increased the soil potassium contents, while the phosphogypsum rates promoted linear increases in soil calcium and sulfur contents. The base saturation was increased and the magnesium content showed a quadratic response on the layer 0.21-0.4 $\mathrm{m}$ with the increase in phosphogypsum rates. The calcium, magnesium and phosphorus contents in the alfalfa leaves were lower with vinasse application. The phosphogypsum rates promoted linear increases in alfalfa SDW. Vinasse rated $150 \mathrm{~m}^{3}$ $\mathrm{ha}^{-1}$ was been enough to SDW increase. Calcium and magnesium contents in the leaves fitted a quadratic model, with maximum calcium content in the phosphogypsum rate of $9.5 \mathrm{Mg} \mathrm{ha}^{-1}$ and the minimum magnesium content in the phosphogypsum rate of $8.7 \mathrm{Mg} \mathrm{ha}^{-1}$. The leaf sulfur contents in all vinasse rates and leaf potassium contents in the highest vinasse rate showed maximum accumulation at near $9 \mathrm{Mg} \mathrm{ha}^{-1}$ of phosphogypsum.
\end{abstract}

Keywords: Medicago sativa. Calcium. Magnesium. Potassium. Sulfur.

\section{APLICAÇÃO DE GESSO E VINHAÇA: ATRIBUTOS QUÍMICOS DO SOLO, PRODUTIVIDADE E ESTADO NUTRICIONAL DA ALFAFA}

RESUMO - O objetivo do trabalho foi avaliar os efeitos da aplicação de gesso e vinhaça na produção de matéria seca, nutrição e atributos químicos do solo cultivado com alfafa. O experimento foi realizado em delineamento experimental de blocos ao acaso, em esquema fatorial $3 \times 5$, com três doses de vinhaça, $0,150 \mathrm{e}$ $300 \mathrm{~m}^{3} \mathrm{ha}^{-1}$ e cinco doses de gesso agrícola $\left(0,3,6,9\right.$ e $\left.12 \mathrm{Mg} \mathrm{ha}^{-1}\right)$. Foram avaliados a composição química e matéria seca da parte aérea (MSPA) e os atributos químicos do solo (0-0,2 e 0,21-0,4 m). As doses de vinhaça aumentaram os teores de potássio, enquanto as doses de gesso promoveram acréscimos lineares nos teores de cálcio e enxofre no solo. A saturação de bases foi crescente e o magnésio teve efeito quadrático na camada de 0,21-0,4 m em função das doses de gesso. Os teores de cálcio, magnésio e fósforo na folha da alfafa foram menores com a aplicação de vinhaça. As doses de gesso promoveram acréscimos lineares na MSPA da alfafa. A dose de $150 \mathrm{~m}^{3} \mathrm{ha}^{-1}$ já foi suficiente para aumentar a MSPA. Os teores de cálcio e magnésio na folha tiveram ajuste quadrático, com máximo acúmulo de cálcio em $9,5 \mathrm{Mg} \mathrm{ha}^{-1} \mathrm{e}$ o magnésio com ponto de mínimo na dose de $8,7 \mathrm{Mg} \mathrm{ha}^{-1}$ de gesso. Os teores foliares de enxofre sob doses de vinhaça e os de potássio na maior dose obtiveram máximo acumulo na presença de $9 \mathrm{Mg} \mathrm{ha}^{-1}$ de gesso.

Palavras-chave: Medicago sativa. Cálcio. Magnésio. Potassio. Enxofre.

\footnotetext{
*Corresponding author

${ }^{1}$ Received for publication in $01 / 30 / 2015$; accepted in 08/03/2016.

Paper extracted from development research of the last two authors, with CNPQ resources.

${ }^{2}$ Department of Agronomy, Universidade Estadual de Londrina. Londrina, PR, Brazil; ronaldonasc@yahoo.com.br, julianasouzaagro@yahoo.com.br.

${ }^{3}$ Embrapa Soja, Empresa Brasileira de Pesquisa Agropecuária, Londrina, PR, Brazil; adonismoreira66@gmail.com, larissa.moraes@embrapa.br.
} 


\section{INTRODUCTION}

The Brazilian sugarcane production has been standing out, mainly due to its high yields and high energy efficiency, achieved especially on the ethanol processing. Each liter of ethanol produced generates 14 liters of vinasse waste, which is potentially polluting when not properly treated, presenting acidifying effect, high nitrate levels and can reduce the concentration of oxygen available when applied in large amounts (BLEY JUNIOR et al., 2009; FUESS; GARCIA, 2014).

Vinasse is applied usually in sugarcane crop areas, aiming to minimize the environmental impact and reintroduce the nutrients exported (SILVA; GRIEBELER; BORGES, 2007). Therefore, vinasse improves soil fertility, supplying nutrients such as potassium $\left(\mathrm{K}^{+}\right)$, calcium $\left(\mathrm{Ca}^{2+}\right)$ and magnesium $\left(\mathrm{Mg}^{2+}\right)$ and organic matter (OM), which have average concentrations of 4.92, 2.08, 0.49 and $2.70 \mathrm{~g} \mathrm{~L}^{-1}$ in the vinasse, respectively (LEITE, 1999).

The application of vinasse has increased sugarcane production (SILVA; BONO; PEREIRA, 2014). Basso et al. (2013) used vinasse for $100 \%$ of potassium fertilization, applying $200 \mathrm{~m}^{3} \mathrm{ha}^{-1}$ of vinasse and found an increase of almost $10 \%$ in $\mathrm{K}^{+}$ content in the topsoil, and increases of 7 to $15 \mathrm{Mg} \mathrm{ha}^{-1}$ in sugarcane yield. Other studies also reported increases in $\mathrm{K}^{+}, \mathrm{Ca}^{2+}, \mathrm{Mg}^{2+}$ and $\mathrm{S}_{-} \mathrm{SO}_{4}{ }^{2-}$ contents due to vinasse application (CARVALHO et al., 2013; SILVA; BONO; PEREIRA, 2014; PAULA; CARVALHO; NOGUEIRA, 1992; ANDREOTTI et al. 2015).

Liming and vinasse application to the soil surface usually reach shallow depths, thus, alternatives to improve acidity correction of soil subsurface are needed. Caires, Feldhaus and Blum (2001) compared mechanical incorporation of lime and use phosphogypsum and found increases of nutrients in the soil subsurface layers and consequently, improvement of plant nutrition, due to nutrient mobilization in the soil profile, and recovery of the nitrogen translocated to the subsurface. Other studies also reported increases in $\mathrm{Ca}^{2+}, \mathrm{Mg}^{2+}, \mathrm{K}^{+}$and $\mathrm{S}_{-} \mathrm{SO}_{4}{ }^{2-}$ contents in subsurface due to lime incorporation and use phosphogypsum (CAIRES et al., 2004; CAIRES; JORIS; CHURKA, 2011; MICHALOVICZ et al., 2014; PAULETTI et al., 2014).

The cultivation of plants that require high fertility and have deep root systems, such as alfalfa, need good soil conditions (MOREIRA et al., 2007), with good nutrient distribution in the soil profile. Silva, Bono and Pereira (2014) found significant increases in $\mathrm{K}^{+}$contents up to the depth of $0.4 \mathrm{~m}$ due to vinasse application $\left(400 \mathrm{~m}^{3} \mathrm{ha}^{-1}\right)$. Caires, Feldhaus and Blum (2001) and Caires et al. (2004) reported increases in the $\mathrm{Ca}^{2+}$ and $\mathrm{Mg}^{2+}$ contents up to the depth of $0.6 \mathrm{~m}$, and Sumner (2009) found high concentrations of alfalfa roots in layers deeper than
$0.2 \mathrm{~m}$, with phosphogypsum application.

In this context, the objective of this work was to assess the variations in soil chemical properties and the productivity and nutritional characteristics of alfalfa (Medicago sativa), depending on the application of different rates of phosphogypsum and vinasse.

\section{MATERIAL AND METHODS}

The experiment was conducted under field conditions in the experimental station of the Embrapa Southwest Livestock, located in São Carlos, São Paulo, Brazil (21 $\left.{ }^{\circ} 59^{\prime} 37^{\prime \prime S}, 47^{\circ} 52^{\prime} 38^{\prime \prime W}\right)$. The region has average altitude of 830 meters, and its climate is Cwa, characterized as tropical of altitude with dry winter and rainy and warm summer, according to the Köppen classification.

The experimental area was cultivated using a central pivot irrigation. The soil was classified as an Oxisol (dystrophic Red-Yellow Latosol - SiBCS), which had the following chemical attributes: $\mathrm{pH}$ in $\mathrm{CaCl}_{2}=4.3$, organic matter $(\mathrm{OM})=27 \mathrm{~g} \mathrm{~kg}^{-1}$, phosphorus $(\mathrm{P})($ resin $)=8.0 \mathrm{mg} \mathrm{kg}^{-1}$, potassium $\left(\mathrm{K}^{+}\right)$ $($ resin $)=0.18 \quad \mathrm{cmol}_{\mathrm{c}} \quad \mathrm{dm}^{-3}, \quad$ calcium $\left(\mathrm{Ca}^{2+}\right)$ $($ resin $)=2.0 \quad \mathrm{cmol}_{\mathrm{c}} \quad \mathrm{dm}^{-3}$, magnesium $\left(\mathrm{Mg}^{2+}\right)$ $($ resin $)=0.70 \quad \mathrm{cmol}_{\mathrm{c}} \quad \mathrm{dm}^{-3}$, aluminum $\left(\mathrm{Al}^{3+}\right)$

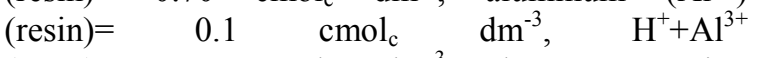
$(\mathrm{SMP})=2.9 \quad \mathrm{cmol}_{\mathrm{c}} \quad \mathrm{dm}^{-3}$, base saturation $(\mathrm{V} \%)=50($ EMBRAPA, 2009). The soil presented sand, silt and clay contents of 479, 144 and $377 \mathrm{~g} \mathrm{~kg}^{-1}$ in the layer $0.0-0.2 \mathrm{~m}$, and 415,102 and $483 \mathrm{~g} \mathrm{~kg}^{-1}$ in the layer $0.21-0.4 \mathrm{~m}$, respectively.

The experiment was conducted in a randomized block design, using a $3 \times 5$ factorial arrangement, consisting of three vinasse rates $\left(0,150\right.$ and $\left.300 \mathrm{~m}^{3} \mathrm{ha}^{-1}\right)$ and five phosphogypsum rates $\left(0,3,6,9\right.$ and $\left.12 \mathrm{Mg} \mathrm{ha}^{-1}\right)$, with three replications. The vinasse contained $1.2 \mathrm{~g} \mathrm{~L}^{-1}$ of $\mathrm{K}_{2} \mathrm{O}$, $0.18 \mathrm{~g} \mathrm{~L}^{-1}$ of $\mathrm{CaO}, 0.088 \mathrm{~g} \mathrm{~L}^{-1}$ of $\mathrm{MgO}$ and its $\mathrm{pH}_{(\mathrm{CaCl})}$ was 4.3. The soil fertilization was carried out with $\mathrm{P}$ (superphosphate; 21\% of $\mathrm{P}_{2} \mathrm{O}_{5}$ ) and micronutrients ( $\mathrm{B}, \mathrm{Cu}, \mathrm{Fe}, \mathrm{Mn}$ e $\mathrm{Zn}$ ), which were added to the seed furrows. The treatments were applied as topdressing. The nutrient rates used were according the recommendations of Moreira et al., (2007), except K and S. A dolomitic lime (Relative Power of Total Neutralization $=95 \%$ ) application was carried out thirty days before planting, which was calculated to increase the base saturation to $80 \%$ (MOREIRA et al., 2007).

The plots consisted of 8 rows with length of 7 meters and $0.2 \mathrm{~m}$ between rows, considering for evaluations the central $6 \mathrm{~m}^{2}$, discarding the borders. The alfalfa cultivar used was the Crioula. The alfalfa seeds were inoculated with Rhizobium meliloti, (strain SEMIA-116) before planting, along with a Mo, Co and Ni solution (MOREIRA et al., 2007). The plant population of 150 to 200 plants $\mathrm{m}^{-2}$ was 
achieved by planting the equivalent to $20 \pm 2 \mathrm{~kg} \mathrm{ha}^{-1}$ of seeds.

Irrigation was performed in periods of low precipitation, applying a water depth of $16.3 \mathrm{~mm}$ every four days, adjusted with a tensiometer. Four alfalfa cuts were performed, 30 days apart. The first cut was three months after the full establishment of the alfalfa crop. The plant material was dried in a forced-air oven at $65^{\circ} \mathrm{C}$ to a constant weight to obtain the shoot dry weight (SDW), the samples were ground in a Wiley mill and taken to the laboratory for determination of macro and micronutrients according to Malavolta, Vitti and Oliveira (1997) and Embrapa (2009).

Phosphorus content in the shoot were determined by the metavanadate colorimetric method, using UV-VIS; K by the flame photometry method; $\mathrm{Ca}$ and $\mathrm{Mg}$ by atomic emission spectrometry (ICP-AES); and $\mathrm{S}$ by the $\mathrm{BaSO}_{4}$ turbidimetry. (MALAVOLTA; VITTI; OLIVEIRA, 1997).

Soil samples were collected in the layers 0.0-0.2 $\mathrm{m}$ and $0.21-0.4 \mathrm{~m}$ soon after the fourth alfalfa cut. The soil samples were air dried in order to assess the $\mathrm{pH}, \mathrm{P}$ and $\mathrm{S}$ available, as well as the contents of exchangeable $\mathrm{K}, \mathrm{Ca}$ and $\mathrm{Mg}$, according to the methodology described in Embrapa (2009).

The results were subjected to analysis of variance (ANOVA; $\mathrm{F}$ test $\mathrm{p} \leq 0.05$ ) and, when significance and interaction between factors were found, each vinasse rate was subjected to regression analysis as a function of phosphogypsum rates; when no interaction were found, the vinasse rates were subjected to the Tukey's test, and the average of the three vinasse rates was subjected to regression analysis as a function of the phosphogypsum rates.

\section{RESULTS AND DISCUSSION}

The soil chemical analysis indicated that the phosphogypsum increased the $\mathrm{S}^{-\mathrm{SO}_{4}}{ }^{2-}$ levels (Table 1). These results confirm those found by Caires, Feldhaus and Blum (2001), Caires et al. (2004), Michalovicz et al. (2014) and Pauletti et al. (2014). Increases in leaf $\mathrm{S}$ are usually directly related to the nutrient supply due to phosphogypsum application (RAIJ, 2011), as observed in this study.

Increase the soil sulfate content has various implications. Zambrosi, Alleoni and Caires (2007) studied ionic speciation involving sulfate and found higher susceptibility to pair formation between $\mathrm{SO}_{4}{ }^{2-}$ and $\mathrm{Ca}^{2+}$, however representing only $1 \%$ of the $\mathrm{Ca}^{2+}$ in solution, with more significant pair formation with $\mathrm{Mg}^{2+}, \mathrm{Al}^{3+}$ and $\mathrm{K}^{+}$(CAIRES et al., 2004; PAULETTI et al., 2014).

The layer $0.0-0.2 \mathrm{~m}$ had no decrease in $\mathrm{K}^{+}$ contents with increasing phosphogypsum rates, however, the soil $\mathrm{Ca}^{2+}$ content showed an increase (Table 1).

Table 1. Regression equations fitted to $\mathrm{K}^{+}, \mathrm{Ca}^{2+}, \mathrm{Mg}^{2+}$ and $\mathrm{S}_{-} \mathrm{SO}_{4}{ }^{2-}$ contents and base saturation (V\%) of soil samples, collected in the layers $0.0-0.2$ and $0.21-0.4 \mathrm{~m}$ at the end of the experiment, depending on phosphogypsum rates.

\begin{tabular}{|c|c|c|c|c|c|}
\hline Layer & Nutrients & Equation & $\mathrm{P}$ & $\mathrm{R}^{2}$ & CV (\%) \\
\hline \multirow{5}{*}{$0.0-0.2 \mathrm{~m}$} & Potassium & $\overline{\mathrm{Y}}=0.17$ & ns & - & 12.0 \\
\hline & Calcium & $Y=2.9+0.29 x$ & $\mathrm{p} \leq 0.001$ & 0.86 & 7.27 \\
\hline & Magnesium & $\bar{Y}=1.51$ & ns & - & 9.92 \\
\hline & Sulfate & $Y=33.4+29.289 x$ & $\mathrm{p} \leq 0.001$ & 0.97 & 8.00 \\
\hline & $\mathrm{V}(\%)$ & $\bar{Y}=68.20$ & ns & - & 8.62 \\
\hline \multirow{5}{*}{$0.21-0.4 \mathrm{~m}$} & Potassium & $\overline{\mathrm{Y}}=0.05$ & ns & - & 16.59 \\
\hline & Calcium & $Y=1.5+0.103 x$ & $\mathrm{p} \leq 0.001$ & 0.97 & 9.76 \\
\hline & Magnesium & $Y=1.009+0.059 x-0.006 x^{2}$ & $\mathrm{p} \leq 0.05$ & 0.75 & 8.46 \\
\hline & Sulfate & $Y=12.93+11.589 x$ & $\mathrm{p} \leq 0.001$ & 0.86 & 8.54 \\
\hline & V (\%) & $\mathrm{Y}=44.8+1.467 \mathrm{x}$ & $\mathrm{p} \leq 0.001$ & 0.89 & 7.32 \\
\hline
\end{tabular}

ns $=$ not significant

Similar effects were observed by Carvalho et al. (2013), who found increases in $\mathrm{Ca}^{2+}$ and sulfate contents in the soil layers $0.0-0.2 \mathrm{~m}$ with the phosphogypsum application, and a consequent increase in base saturation ( $\mathrm{V} \%$ ), which is directly related to the displacement of hydroxyl $\left(\mathrm{OH}^{-}\right)$and sulfate adsorption, enabling the formation of metal binders, increasing the cation exchange capacity (CEC) predominantly related to the cation $\mathrm{Ca}^{2+}$ (RAIJ, 2011).

Linear increases in base saturation in the layer
0.21-0.4 $\mathrm{m}$ was found (Table 1), showing an improvement of fertility in the soil profile. Rampim and Lana (2015) and Soratto and Crusciol (2008) evaluated the application phosphogypsum rates and also found increases in base saturation in the soil layer 0.21-0.4 m. Both studies showed the phosphogypsum as responsible for the soil conditioning. Effects similar to those found in the layer $0.0-0.2 \mathrm{~m}$ were found in the layer 0.21-0.4 m, as also found by Pauletti et al. (2014) with phosphogypsum application, with a reduced 
availability of $\mathrm{Mg}^{2+}$ in soil layer $0.21-0.4 \mathrm{~m}$.

The base saturation increased in the layer 0.21-0.4 $\mathrm{m}$, and the $\mathrm{Ca}^{2+}$ contents increased in the surface layer, however with small reductions in $\mathrm{Mg}^{2+}$ contents. Caires et al. (2004) found increases in corn gain yield due to increase in $\mathrm{CEC}$ by $\mathrm{Ca}^{2+}$ saturation. Rampim et al. (2011) found that an increase in saturation occurring due to the leaching and neutralization of $\mathrm{Al}^{3+}$ to subsurface layers. In the present work, the $\mathrm{H}^{+}+\mathrm{Al}^{3+}$ contents presented no changes in any of the phosphogypsum rates applied, probably due to the lime application.
The application of vinasse increased the $\mathrm{K}^{+}$ content in the soil layers $0.0-0.2 \mathrm{~m}$ and $0.21-0.4 \mathrm{~m}$ (Table 2) and was not affected by the phosphogypsum. Carvalho et al. (2013) found different results, with reductions in $\mathrm{K}^{+}$contents in a soil of sandier texture, which differ from the soil of the present study, which had around $400 \mathrm{~g} \mathrm{~kg}^{-1}$ of soil. This difference in texture, may explain the difference in $\mathrm{K}$ contents, since, according to Brito (2009), who studied the $\mathrm{K}$ movement in the soil surface layers, differences in $\mathrm{K}$ contents are related to the soil texture.

Table 2. Analysis of variance of average potassium, calcium, magnesium, sulfate contents and base saturation (V\%) of the soil layers $0.0-0.2 \mathrm{~m}$ and $0.21-0.4 \mathrm{~m}$ depending on vinasse rates.

\begin{tabular}{|c|c|c|c|c|c|}
\hline $\begin{array}{c}\text { Vinasse Rates } \\
\left(\mathrm{m}^{3} \mathrm{ha}^{-1}\right)\end{array}$ & $\begin{array}{c}\text { Potassium } \\
\left(\mathrm{cmol}_{\mathrm{c}} \mathrm{dm}^{-3}\right)\end{array}$ & $\begin{array}{c}\text { Calcium } \\
\left(\mathrm{cmol}_{\mathrm{c}} \mathrm{dm}^{-3}\right)\end{array}$ & $\begin{array}{l}\text { Magnesium } \\
\left(\mathrm{cmol}_{\mathrm{c}} \mathrm{dm}^{-3}\right)\end{array}$ & $\begin{array}{c}\text { Sulfate } \\
\left(\mathrm{mg} \mathrm{dm}^{-3}\right)\end{array}$ & $\mathrm{V} \%$ \\
\hline \multicolumn{6}{|c|}{ Soil layer $0.0-0.2 \mathrm{~m}$} \\
\hline 0 & $0.13 \mathrm{a}$ & $4.63 \mathrm{a}$ & 1.49 & 208.73 & 68.20 \\
\hline 150 & $0.20 \mathrm{~b}$ & $4.78 \mathrm{a}$ & 1.27 & 245.07 & 64.47 \\
\hline 300 & $0.24 \mathrm{c}$ & $4.13 \mathrm{~b}$ & 1.19 & 204.31 & 63.47 \\
\hline $\mathrm{F}$ test & $* *$ & $* *$ & ns & ns & ns \\
\hline CV (\%) & 12.76 & 10.72 & 13.87 & 10.16 & 8.69 \\
\hline \multicolumn{6}{|c|}{ Soil layer $0.21-0.4 \mathrm{~m}$} \\
\hline 0 & $0.07 \mathrm{~b}$ & 1.96 & 1.07 & 97.47 & 53.60 \\
\hline 150 & $0.08 \mathrm{a}$ & 1.84 & 0.94 & 116.47 & 46.13 \\
\hline 300 & $0.09 \mathrm{a}$ & 1.84 & 0.99 & 110.00 & 46.47 \\
\hline F test & $* *$ & ns & ns & ns & ns \\
\hline CV (\%) & 16.71 & 10.96 & 12.57 & 15.32 & 12.29 \\
\hline
\end{tabular}

ns $=$ not significant, $* \mathrm{p} \leq 0.05 ; * * \mathrm{p} \leq 0.01$

The $\mathrm{K}^{+}$results differ from those found by Rampim et al. (2011) who studied the effects of phosphogypsum rates in an Oxisol (eutropherric Red Latosol - SiBCS) and reported a $\mathrm{K}$ displacement from the soil surface layers to depths below $0.2 \mathrm{~m}$, resulting in an increase in the subsurface layers. The $\mathrm{K}$ contents in the present work was similar to those found by Carvalho et al. (2013), who evaluated vinasse rates in a sugarcane crop. The vinasse rates application did not affected the contents of nutrients, except calcium in the soil layer $0.0-0.2 \mathrm{~m}$ and potassium in both layers. Andreotti et al. (2015) assessed the changes in the soil under vinasse applications of up to $200 \mathrm{~m}^{3}$ and found similar results, with the main effects related to the large amount of potassium present in the vinasse.

The SDW presented linear increases depending on the phosphogypsum rates, and did not differ with vinasse rates of 150 and $300 \mathrm{~m}^{3} \mathrm{ha}^{-1}$, both surpassing the control (Table 3). Similar results of yield increases were observed in sugarcane by Silva, Bono and Pereira, (2014) and in maize by Caires et al. (2004), with vinasse and phosphogypsum application, respectively. According to Carvalho et al. (2013), these increases are due to the improvement of soil fertility with $\mathrm{Ca}^{2+}$ and $\mathrm{S}_{-} \mathrm{SO}_{4}{ }^{2-}$ (Table 1) by the phosphogypsum and the large quantities of potassium present in the vinasse (Table 2), both improving the soil conditions.

Leaf nutrient contents are usually correlated to increased yield, as reported by Paula, Carvalho and Nogueira (1992), who studied increasing rates of vinasse on onion crops and found for a maximum yield the rate of $160 \mathrm{~m}^{3}$ per ha' $\mathrm{h}^{-1}$, which increased the leaf $\mathrm{K}^{+}$, differing from the control which showed nutrient deficiency symptoms and low yield.

The $\mathrm{K}$ and $\mathrm{S}$ contents presented significant interaction for the phosphogypsum and vinasse applications. The $\mathrm{S}$ contents increased with the increasing vinasse rates, and showed a quadratic fit to the phosphogypsum rates (Figure 1B). These results confirm those found by Moreira, Carvalho and Evangelista (1997), who reported increases in S content followed by a similar increase in dry weight, however, the results of $\mathrm{K}^{+}$were similar only to the vinasse rate of $300 \mathrm{~m}^{3} \mathrm{ha}^{-1}$, with no significant interaction to the other vinasse rates depending on the phosphogypsum rates (Figure 1A). 
Table 3. Analysis of variance of alfalfa shoot dry weight (SDW) and leaf nutritional content depending on vinasse $\left(\mathrm{m}^{3} \mathrm{ha}^{-1}\right)$ and phosphogypsum $\left(\mathrm{Mg} \mathrm{ha}^{-1}\right)$ rates, using average values from four cuts.

\begin{tabular}{|c|c|c|c|c|c|c|}
\hline Rates & $\begin{array}{l}\text { SDW } \\
\left(\mathrm{g} \mathrm{kg}^{-1}\right) \\
\end{array}$ & $\begin{array}{c}\text { Calcium } \\
\left(\mathrm{g} \mathrm{kg}^{-1}\right)\end{array}$ & $\begin{array}{c}\text { Magnesium } \\
\left(\mathrm{g} \mathrm{kg}^{-1}\right)\end{array}$ & $\begin{array}{c}\text { Phosphorus (g } \\
\mathrm{kg}^{-1} \text { ) }\end{array}$ & $\begin{array}{c}\text { Potassium (g } \\
\left.\mathrm{mg}^{-1}\right)\end{array}$ & $\begin{array}{r}\text { Sulfur } \\
\left(\mathrm{g} \mathrm{kg}^{-1}\right) \\
\end{array}$ \\
\hline & & 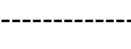 & - Vinasse ---- & - & --------- & \\
\hline 0 & $1467.36 \mathrm{~b}$ & $13.90 \mathrm{a}$ & $3.07 \mathrm{a}$ & $3.06 \mathrm{a}$ & 27.11 & 4.76 \\
\hline 150 & $1574.93 \mathrm{a}$ & $11.86 \mathrm{~b}$ & $2.47 \mathrm{~b}$ & $2.92 \mathrm{ab}$ & 30.12 & 4.28 \\
\hline 300 & $1606.50 \mathrm{a}$ & $12.06 \mathrm{~b}$ & $2.46 \mathrm{~b}$ & $2.89 \mathrm{~b}$ & 32.19 & 4.33 \\
\hline F test & $* *$ & $* *$ & $* *$ & $*$ & - & - \\
\hline $\mathrm{CV}(\%)$ & 7.65 & 6.08 & 5.31 & 5.36 & 5.97 & 6.17 \\
\hline 0 & 1436 & 10.98 & 3.06 & 2.87 & 29.4 & 3.43 \\
\hline 3 & 1494 & 12.47 & 2.69 & 2.92 & 29.85 & 4.45 \\
\hline 6 & 1533 & 13.32 & 2.61 & 2.98 & 30.17 & 4.83 \\
\hline 9 & 1654 & 12.84 & 2.41 & 2.94 & 30.56 & 4.68 \\
\hline 12 & 1631 & 13.43 & 2.57 & 3.06 & 29.05 & 4.9 \\
\hline Effect & $\mathrm{L} / 0.89^{* *}$ & $\mathrm{Q} / 0.89^{*}$ & $\mathrm{Q} / 0.95^{* *}$ & ns & - & - \\
\hline Interaction & ns & ns & ns & ns & $*$ & $*$ \\
\hline CV (\%) & 7.65 & 6.08 & 5.31 & 5.36 & 5.97 & 6.17 \\
\hline
\end{tabular}

$\mathrm{ns}=$ not significant. ${ }^{*} \mathrm{p} \leq 0.05 ; * * \mathrm{p} \leq 0.01$. Means followed by the same letter in the column do not differ from each other by the Tukey test. SDW $=18.37 \mathrm{x}+1439.4, \mathrm{Ca}=-0.025 \mathrm{x}^{2}+0.47 \mathrm{x}+11.11, \mathrm{Mg}=0.0074 \mathrm{x}^{2}-0.13 \mathrm{x}+3.05$.
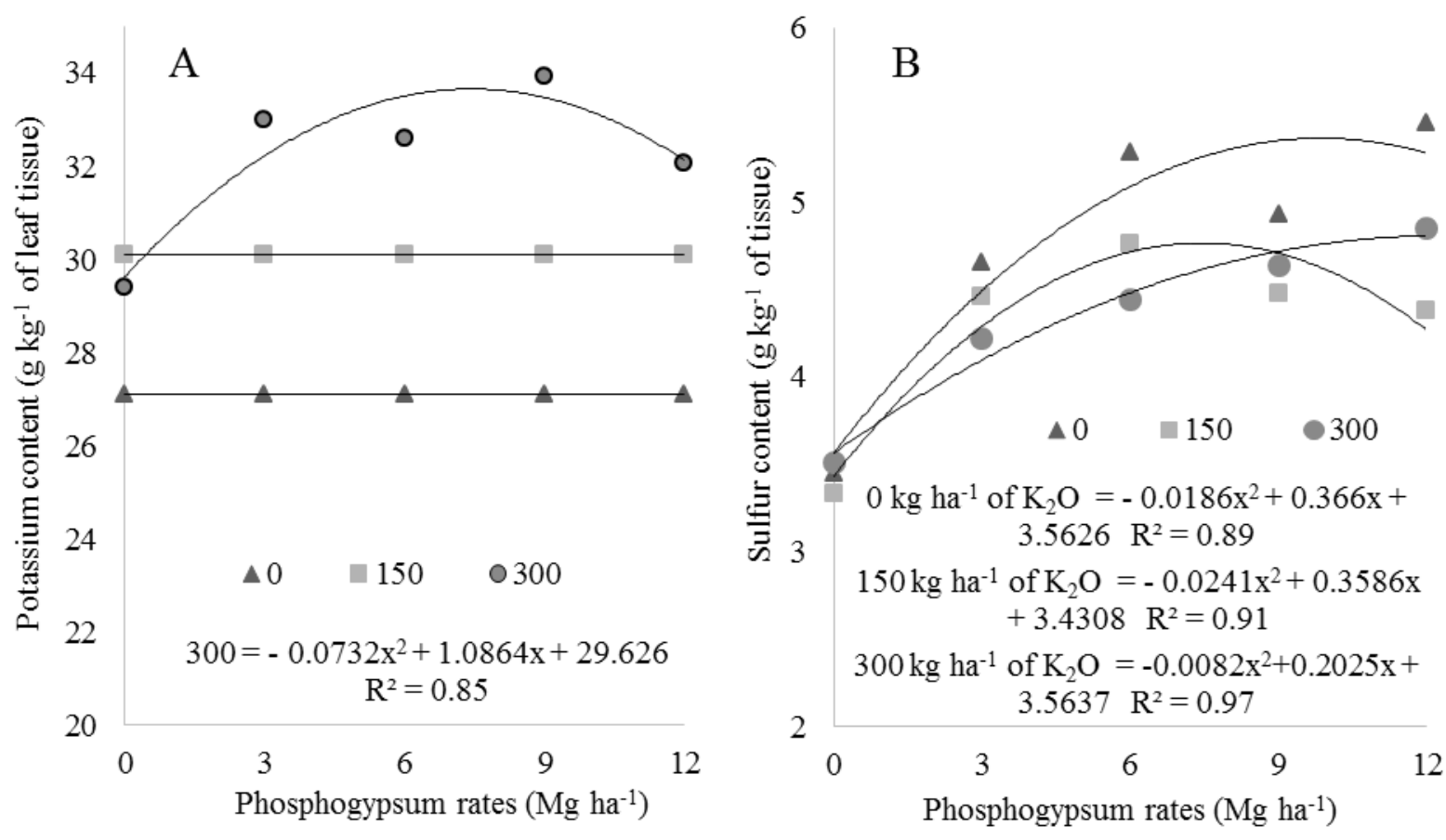

Figure 1. Potassium (A) and sulfur (B) contents in alfalfa leaves depending on three vinasse rates $\left(0,150\right.$ and $\left.300 \mathrm{~m}^{3} \mathrm{ha}^{-1}\right)$ and five phosphogypsum rates $\left(0,3,6,9\right.$ and $\left.12 \mathrm{Mg} \mathrm{ha}^{-1}\right)$, using average values from four cuts.

The vinasse application, especially at a rate of $300 \mathrm{~m}^{3} \mathrm{ha}^{-1}$, increased the $\mathrm{K}$ content, which is related to the phosphogypsum application, with linear increases in $\mathrm{Ca}$ and a quadratic response in $\mathrm{Mg}$ in the layer 0.21-0.4 m, probably promoting competitive inhibition between $\mathrm{Ca}$ and $\mathrm{K}$ (MALAVOLTA, 2006). The most marked inhibition was observed in the $\mathrm{K}$ with $\mathrm{Mg}$, as reported by Carvalho et al. (2013) and Ferreira Neto et al. (2014) and between $\mathrm{Ca}$ and $\mathrm{Mg}$ (SOUZA et al., 2012), showing that, from 
7.42 $\mathrm{Mg} \mathrm{ha}^{-1}$, due to the large amount of $\mathrm{Ca}$, the $\mathrm{K}$ uptake decreases.

The increase in $\mathrm{K}$ contents with the lower phosphogypsum rates, according to Caires, Feldhaus and Blum (2001), who studied barley (Hordeum vulgare), is due the increase in $\mathrm{Ca}$ in the soil, which displace the $\mathrm{K}$ to the soil solution, making it available to absorption. According to Michalovicz et al. (2014), the leaf $\mathrm{K}$ content is related to its availability in the soil, and the phosphogypsum application can change this nutrient dynamic in the soil.

The leaf $\mathrm{P}$ showed no changes as a function of phosphogypsum rates, however, the Ca showed a quadratic response and maximum accumulation with an estimated phosphogypsum rate of $4.5 \mathrm{mg} \mathrm{ha}^{-1}$. These results differ from those reported by Vicensi et al (2016), who studied a soil with lower Ca contents and found a linear fit up to $12 \mathrm{mg} \mathrm{ha}^{-1}$.

\section{CONCLUSIONS}

The phosphogypsum rates promoted linear increases of soil calcium and sulfate contents, however, did not change the potassium contents in the layer $0.0-0.4 \mathrm{~m}$. The base saturation increased linearly and the magnesium contents showed a quadratic response in the layer 0.21-0.4 m.

The vinasse rates increased only the soil potassium contents, up to the depth of $0.4 \mathrm{~m}$. The increase in phosphogypsum rates promoted linear increases of alfalfa shoot dry weight (SDW), and its maximum production was reached with the vinasse rate of $150 \mathrm{~m}^{3} \mathrm{ha}^{-1}$.

The calcium, magnesium and phosphorus contents were lower with vinasse application. Calcium contents showed a quadratic fit, with maximum accumulation at $9.5 \mathrm{Mg} \mathrm{ha}{ }^{-1}$, and magnesium showed minimal accumulation at 8.7 $\mathrm{Mg} \mathrm{ha}^{-1}$ of phosphogypsum. The contents of sulfur in all vinasse rates and potassium at rate of $300 \mathrm{~m}^{3} \mathrm{ha}^{-1}$ had maximum accumulation at near $9 \mathrm{Mg} \mathrm{ha}^{-1}$ of phosphogypsum.

\section{REFERENCES}

ANDREOTTI, M. et al. Acúmulo de nutrientes e decomposição do palhiço de cana em função de doses de vinhaça. Bioscience Journal, Uberlândia, v. 31, n. 2, p. 563-576, 2015.

BASSO, C. J. et al. Vinhaça como fonte de potássio: resposta da sucessão aveia-preta/milho silagem/ milho safrinha e alterações químicas do solo na Região Noroeste do Rio Grande do Sul. Ciência Rural, Santa Maria, v. 43, n. 4, p. 596-602, 2013.
BLEY JUNIOR, C. et al. Agroenergia da Biomassa Residual: perspectivas energéticas, socioeconômicas e ambientais. 2. ed. Foz do Iguaçu, PR: TECHNOPOLITIK, 2009. 140 p.

BRITO, F. L. ROLIM, M. M.; PEDROSA, E. M. R. Efeito da aplicação de vinhaça nas características químicas de solos da zona da mata de Pernambuco. Revista Brasileira de Ciências Agrárias, Pernambuco, v. 4, n. 4, p. 456-462, 2009.

CAIRES, E. F. et al. Alterações químicas do solo e resposta do milho à calagem e aplicação de gesso. Revista Brasileira de Ciência do Solo, Viçosa, v. 28, n. 1.p. 125-136, 2004.

CAIRES, E. F.; FELDHAUS, I. C.; BLUM, J. Crescimento radicular e nutrição da cevada em função da calagem e aplicação de gesso. Bragantia, Campinas, v. 60, n. 3, p. 213-223, 2001.

CAIRES, E. F.; JORIS, H. A. W.; CHURKA, S. Long-term effects of lime and gypsum additions on no-till corn and soybean yield and soil chemical properties in southern Brazil. Revista Brasileira de Ciência do solo, Viçosa, v. 27, n. 1, p. 45-53, 2011.

CARVAlHO, J. M. et al. Produtividade de cana soca sem queima em função do uso de gesso e vinhaça. Pesquisa Agropecuária Tropical, Goiânia, v. 43 , n. 1, p. 1-9, 2013

EMBRAPA. Manual de análises químicas de solos, plantas e fertilizantes. 2. ed. Brasília, DF: EMBRAPA INFORMAÇÃO TECNOLOGICA, 2009. 370 p.

FERREIRA NETO, M. et al. Atributos químicos do solo e estado nutricional de coqueiro anão fertigado com nitrogênio e potássio. Revista Caatinga, Mossoró, v. 27, n. 3, p. 30-40, 2014.

FUESS, L. T.; GARCIA, M. L. Implications of stillage land disposal: A critical review on the impacts of fertigation. Journal of Environmental Management, New York, v. 145, n. 1, p. 210-229. 2014.

LEITE, G. F. Avaliação econômica da adubação com vinhaça e da adubação mineral de soqueiras de cana-de-açúcar na usina monte alegre Ltda. - Monte Belo - MG. Revista da Universidade de Alfenas, Alfenas, v. 5, n. 3, p. 189-181, 1999.

MALAVOLTA, E. Manual de nutrição mineral de plantas. 1. ed. São Paulo, SP: EDITORA AGRONÔMICA CERES, 2006. 638 p.

MALAVOLTA, E.; VITTI, G. C.; OLIVEIRA, S. A. Avaliação do estado nutricional das plantas: 
princípios e aplicações. 2. ed. Piracicaba, SP: POTAFÓS, 1997. 319 p.

MICHALOVICZ, L. et al. Soil fertility, nutrition and yield of maize and barley with gypsum application on soil surface in no-till. Revista Brasileira de Ciência do Solo, Viçosa, v. 38, n. 5, p. 1496-1505, 2014.

MOREIRA, A.; CARVALHO, J. G.; EVANGELISTA, A. R. Efeito de doses de enxofre na produção e composição mineral da alfafa. Pesquisa Agropecuária Brasileira, Brasília, v. 32, n. 5, p. 533-538, 1997.

MOREIRA, A. et al. Fertilidade do solo e estado nutricional da alfafa cultivada nos trópicos. 1. ed. São Carlos, SP: Embrapa Pecuária Sudoeste, 2007. $40 \mathrm{p}$.

PAULA, M. B; CARVALHO, V. D.; NOGUEIRA, F. D. Efeitos da vinhaça na produção e qualidade da cebola em solo de baixo potencial de produtividade. Pesquisa Agropecuária Brasileira, Brasília, v. 27, n. 3, p. 389-393, 1992.

PAULETTI, V. et al. Efeitos em longo prazo da aplicação de gesso e calcário no sistema de plantio direto. Revista Brasileira de Ciência do Solo, Viçosa, v. 38, n. 2, p. 495-505, 2014.

RAIJ, B. V. Fertilidade do solo e manejo de nutrientes. 1. ed. Piracicaba, SP: IPNI, 2011. 420 p.

RAMPIM, L. et al. Atributos químicos de solo e resposta do trigo e da soja ao gesso em sistema semeadura direta. Revista Brasileira de Ciência do Solo, Viçosa, v. 35, n. 5, p. 1687-1698, 2011.

RAMPIM, L.; LANA, M. C. Ion mobility and base saturation after gypsum application in continuous soybean-wheat cropping system under no-till. Australian Journal of Crop of Science, Australia, v. 9 , n. 6. p. 468-476, 2015.

SILVA, M. A. S., GRIEBELER, N. P., BORGES, L. C. Uso de vinhaça e impactos nas propriedades do solo e lençol freático. Revista Brasileira de Engenharia Agrícola e Ambiental, Campina Grande, v. 11, n. 1, p. 108-114, 2007.

SILVA, A. P. M.; BONO, J. A. M.; PEREIRA, F. A. R. Aplicação de vinhaça na cultura da cana-de-açúcar: Efeito no solo e na produtividade de colmos. Revista Brasileira de Engenharia Agrícola e Ambiental, Campina Grande, v. 18, n. 1, p. 38-43, 2014.

SORATTO, R. P.; CRUSCIOL, C. A. C. Produção de fitomassa e acúmulo de nutrientes pela aveia-preta em função da aplicação de calcário e gesso em superfície na implantação do sistema plantio direto. Ciência Rural, Santa Maria, v. 38, n. 4, p. 928-935. 2008.

SOUZA, M. A. et al. Acúmulo de macronutrientes na soja influenciado pelo cultivo prévio do capim-marandu, correção e compactação do solo. Revista Ciência Agronômica, Fortaleza, v. 43, n. 4, p. 611-622, 2012.

SUMNER, M. Gypsum Improves Subsoil Root Growth. In: INTERNATIONAL SYMPOSIUM ROOT RESEARCH AND APPLICATIONS, 1., 2009, Viena, Anais... Austria: BOKU, 2009, p. 1-4.

VICENSI, M. et al. Do rates and splitting of phosphogypsum applications influence the soil and annual crops in a no-tillage system? Viçosa, Revista Brasileira de Ciência do Solo, Viçosa, v. 40, n. 1, p. 1-17. 2016.

ZAMBROSI, F. C. B.; ALLEONI, L. R. F.; CAIRES, E. F. Aplicação de gesso agrícola e especiação iônica da solução de um Latossolo sob sistema plantio direto. Ciência Rural, Santa Maria, v. 37 , n. 1, p. 110-117, 2007. 